\title{
Immunolocalization of NGF and Its Receptors trkA and p75 in the Oviducts of Golden Hamsters during the Estrous Cycle
}

\author{
Qiang WENG ${ }^{1,2)}$, ZhanQuan $\mathrm{SHI}^{2,3)}$, Gen WATANABE ${ }^{2,3)}$, and Kazuyoshi TAYA ${ }^{2,3)}$ \\ ${ }^{1)}$ College of Biological Science and Technology, Beijing Forestry University, Beijing 100083, China, \\ ${ }^{2}$ Laboratory of Veterinary Physiology, Department of Veterinary Medicine, Faculty of Agriculture, Tokyo \\ University of Agriculture and Technology, Tokyo 183-8509, Japan, and ${ }^{3)}$ Department of Basic Veterinary \\ Science, United Graduate School of Veterinary Sciences, Gifu University, Gifu 501-1193, Japan
}

\begin{abstract}
To investigate the physiological roles of nerve growth factor (NGF) in the oviduct of golden hamsters during the estrous cycle, the localization of NGF and its receptors, trkA and $\mathrm{p} 75$, were determined by immunohistochemistry. Positive staining of NGF, trkA, and p75 was present in epithelial cells and muscle cells of the infundibulum, ampulla, and isthmus in the oviduct. The intensities of the immunohistochemical signals for NGF, trkA, and p75 did not markedly change in any segment of the oviduct during the estrous cycle. These results suggest that NGF may play autocrine/paracrine roles in oviductal transport, fertilization, capacitation of spermatozoa and early embryonic development in the oviduct of golden hamsters.
\end{abstract}

Key words: golden hamster, NGF, oviduct

Mammalian fertilization occurs in the oviduct of the female genital tract. The oviduct and the fluid contained within the oviduct provide a distinct microenvironment that influences sperm capacitation, final oocyte maturation, fertilization, and early embryo development [9]. Oviductal fluid is essential for the oviduct to carry out its reproductive functions [12]. Chemical analyses have indicated that oviductal fluid is a complex mixture of constituents derived from the plasma plus some specific proteins formed by the oviductal epithelium [13]. Previous studies have found that the oviduct contributes bioactive growth factors that are essential for the development of zygotes to the blastocyst stage [4,27]. These growth factors support early embryo development in the oviduct via paracrine and autocrine interactions [9].

Nerve growth factor (NGF) belongs to a family of related proteins required for the survival, maintenance, and development of discrete neuronal populations in the central and peripheral nervous systems $[3,14,23]$. The effect of NGF has been shown to be mediated through a specific membrane receptor, high-affinity tyrosine kinase A (trkA), which is responsible for NGFs biological activities [18, 24]. Furthermore, the effect of NGF is also mediated via the low affinity p75 receptor and other neurotropin receptors [5]. Evidence has accumulated that NGF and its receptors play a critical role in the development of the mammalian ovary, oogenesis, and folliculogensis $[1,6,7,16,21]$. In our previous studies,

(Received 29 March 2009 / Accepted 15 June 2009)

Address corresponding: Q. Weng, Laboratory of Animal Physiology, College of Biological Science and Technology, Beijing Forestry University, 35 East Qinghua Road, Haidian District, Beijing, 100083, China 
the presence of NGF and its two receptors, trkA and p75, was demonstrated in the reproductive organs, demonstrating that NGF and its receptors, trkA and p75, have important autocrine and paracrine regulatory roles in gonadal function $[11,15,21,22]$. Although several observations about the effect of NGF during embryo development in vitro have been reported $[8,17]$, there are still many gaps in the understanding of the mechanisms of oviductal function, especially with regard to the role of NGF and its receptors in oviductal transport, fertilization, capacitation of spermatozoa, and early embryonic development. The present study, therefore, investigated immunolocalization of NGF and its receptors, trkA and $\mathrm{p} 75$, in the oviducts of golden hamsters.

Adult female golden hamsters (Mesocricetus auratus) were housed under controlled temperature $\left(23-25^{\circ} \mathrm{C}\right)$ and lighting (lights on from 05:00 to 19:00). Food and water were available ad libitum. The 4-day estrous cycle was determined by the presence of the characteristic vaginal discharge on the morning of the day of ovulation, which is designated as Day 1 of the estrous cycle. Golden hamsters with at least two consecutive 4-day estrous cycles were used in the present study. All experimental procedures were carried out in accordance with the Guide for the Care and Use of Laboratory Animals prepared by Tokyo University of Agriculture and Technology.

The oviducts were removed at 11:00 on each day of the estrous cycle under ether anesthesia, and were fixed in $4 \%$ paraformaldehyde and embedded in paraffin wax. Serial sections $(4 \mu \mathrm{m})$ were mounted on slides coated with poly-L-lysine (Sigma Diagnostics, St. Louis, MO, USA.) for immunohistochemistry.

Oviduct sections were incubated with $10 \%$ normal goat serum to reduce background staining caused by the second antibody. The procedures used for immunohistochemistry were described in a previous paper [22]. NGF and its receptors NTRK1 (trkA) and TNFRSF1B (p75) were detected by using polyclonal antibodies against NGF $(0.4 \mu \mathrm{g} / \mathrm{ml}, \mathrm{M}-20)$, trkA $(2 \mu \mathrm{g} / \mathrm{ml}, 763)$, and p75 $(2 \mu \mathrm{g} / \mathrm{ml}, \mathrm{H}-92)$ (Santa Cruz Biotechnology, Santa Cruz, CA, USA) to identify NGF, trkA, and p75, respectively. The sections were incubated with primary antibodies to NGF, trkA, and $\mathrm{p} 75$ for $12 \mathrm{~h}$ at room temperature. The sections were then incubated with a sec- ondary antibody, goat anti-rabbit IgG conjugated with biotin and peroxidase with avidin, using a rabbit ExtrAvidin $^{\mathrm{TM}}$ staining kit (Sigma Diagnostics, St. Louis, MO, USA), followed by visualization with $30 \mathrm{mg}$ 3,3-diaminobenzidine (Wako, Tokyo, Japan) solution in $150 \mathrm{ml}$ of 0.05 mol Tris-HCl $1^{-1}$ buffer, $\mathrm{pH}$ 7.6, plus $30 \mu 1 \mathrm{H}_{2} \mathrm{O}_{2}$. Finally, the reacted sections were counterstained with haematoxylin solution (Merck, Tokyo, Japan). The control sections were treated with normal rabbit serum (Sigma Diagnostics, St. Louis, MO, USA) instead of the primary antisera.

Immunohistochemical detection of NGF, trkA, and p75 are shown in Fig. 1. Immunostaining of NGF was present in epithelial cells and muscle cells of all the three segments, infundibulum, ampulla and isthmus, of the oviduct $(\mathrm{a}, \mathrm{b}, \mathrm{c})$. Immunoreactivities of trkA and p75 were shown in the same localizties as those of NGF, the infundibulum, ampulla, and isthmus of the oviduct (d, $\mathrm{e}, \mathrm{f} ; \mathrm{g}, \mathrm{h}, \mathrm{i})$. The intensities of the immunohistochemical signals for NGF, trkA, and p75 did not appear markedly different in the same segment throughout the estrous cycle, and also no variation in staining intensity was found among the three segments of the oviduct in samples taken on each day of the estrous cycle. No immunostaining was detected in control sections in which normal rabbit serum was substituted in place of the primary antibody (data not shown).

The present study clearly demonstrates that positive staining for NGF, trkA, and p75 was present in epithelial cells and muscle cells of the infundibulum, ampulla and isthmus in the oviduct of cyclic golden hamsters.

Oviductal fluid is a complex mixture of plasma-derived constituents plus proteins synthesized by the oviduct epithelium $[25,28]$. It has been reported that the oviduct can secrete many growth factors, such as epidermal growth factor (EGF), transforming growth factor (TGF), insulin-like growth factor (IGF), and activin [10, $19,20]$. These findings indicate that there are likely to be autocrine and paracrine oviductal and embryonic growth factor interactions supporting early embryo development in the oviduct. In the present study, localization of NGF and its receptors trkA and p75 was found in the oviducts of golden hamsters. This is the first report of expression of NGF and its receptors in the oviduct of golden hamsters. Studies of porcine oocytes during in 


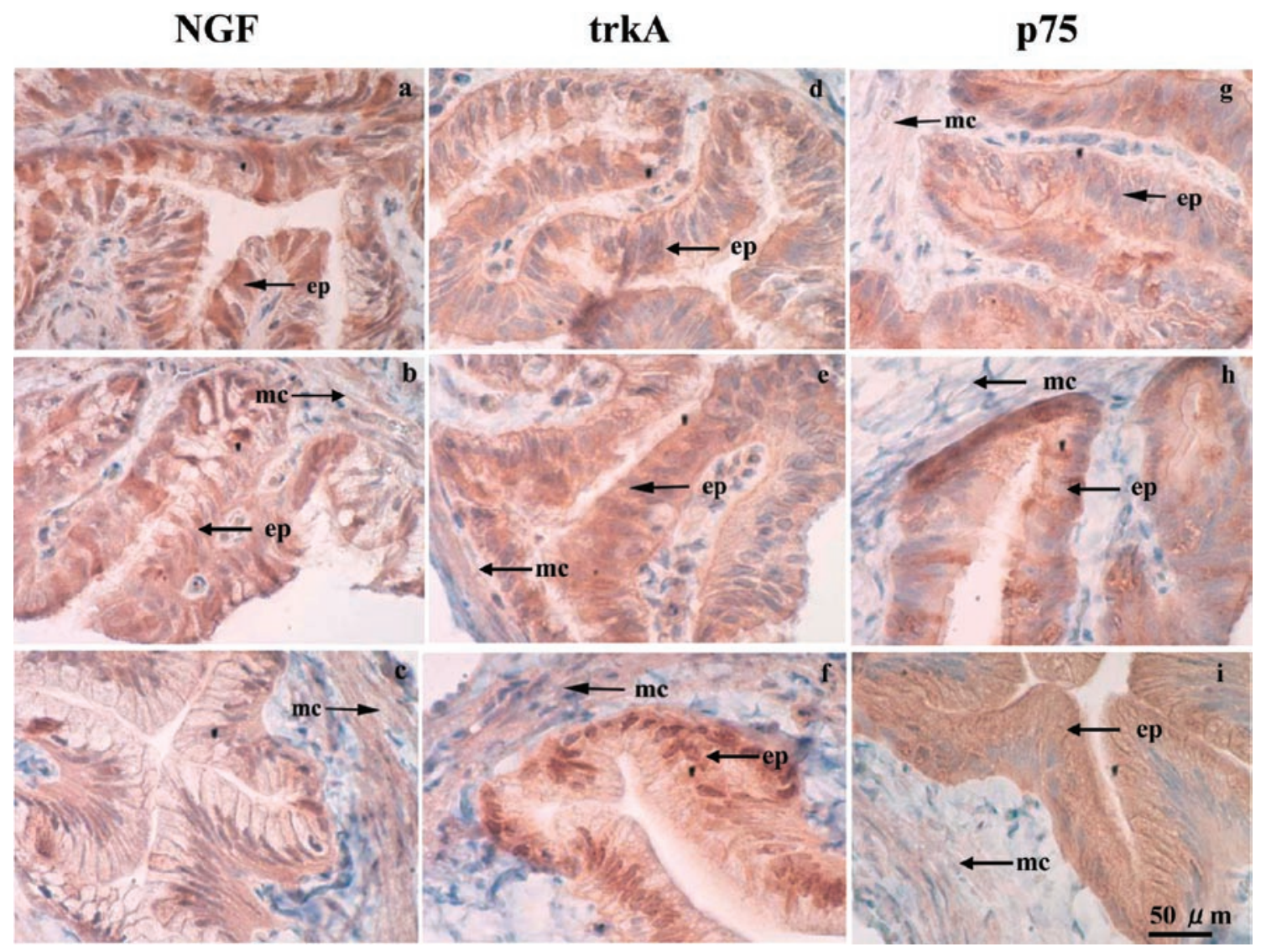

Fig. 1. Immunohistochemical staining of NGF, trkA, and p75 in the oviduct of golden hamsters. Panels a, b, and c are the staining results for NGF in the infundibulum, ampulla, and isthmus, respectively; Panels $d, e$, and $f$ are the staining results for NGF receptor trkA in the infundibulum, ampulla, and isthmus, respectively; Panels $\mathrm{g}$, $\mathrm{h}$, and $\mathrm{i}$ are the staining results for NGF receptor p75 in the infundibulum, ampulla, and isthmus, respectively. Ep, epithelial cell; $\mathrm{mc}$, muscle cells; the scale bar $=50 \mu \mathrm{m}$.

vitro maturation and embryo development have shown that NGF during in vitro maturation accelerates the nuclear progression of porcine oocytes by enhancing the post-diakinetic events of meiosis [17]. Therefore, the present results support the notion that NGF is involved in a paracrine or autocrine network that strives to successfully establish and maintain pregnancy [29].

The female reproductive system undergoes a number of programmed cyclical processes during the course of the ovulatory cycle. NGF and its receptors, under the influence of gonadotropins and/or ovarian hormones, may play a crucial regulatory role in these processes. The roles of NGF and its receptors in the ovary, uterus, and ovarian interstitial cells of golden hamsters have been studied, and these roles and the modulation of expression of NGF and its receptors differs among the various reproductive tissues $[21,22,26]$. In the ovarian tissues of golden hamsters, immunopositive reactions of NGF and its receptors were found in oocytes, theca and granulosa cells of different sized follicles [22]. Positive reactions for NGF and its receptors were also present in interstitial cells during the estrous cycle. Furthermore, the LH surge may be an important factor for stimulating the production of NGF and its two receptors in the interstitial cells of the golden hamster [26]. NGF and its two receptors are present in uteri of golden hamsters and their expression is stimulated by estrogen and progesterone [21]. However, NGF and its receptors' expressions in the oviduct was not affected by estrogen or progesterone in the present study, and the intensities of the immunohistochemical signals for NGF, trkA, and p75 did not appear markedly different during the estrous 
cycle. The present study has data on the immunohistochemistry of NGF, trkA, and p75, and further molecular biology studies will be required to determine the influence of reproductive hormones on NGF production and the possible interaction between oviductal tissue secretions and the early embryo. In conclusion, in the oviduct of golden hamsters, NGF and its two receptors, trkA and p75, are localized in epithelial cells and smooth muscle cells. The localization of NGF, trkA, and p75 in epithelial cells and smooth muscle cells suggests that NGF and its receptors play roles in oviductal transport, fertilization, capacitation of spermatozoa, and early embryonic development in the oviduct.

\section{Acknowledgment(s)}

This study was supported in part by a Grant-in-Aid for Scientific Research (Basic Research B-18310044, P06445) from the Japan Society for the Promotion of Science and a Grant-in-Aid from Program for Changjiang Scholars and Innovative Research Team in Universities (IRT0607) of China and a Grant-in-Aid from the Project Sponsored by the Scientific Research Foundation for the Returned Overseas Chinese Scholars, State Education Ministry.

\section{References}

1. Abir, R., Fisch, B., Jin, S., Barnnet, M., Ben-Haroush, A., Felz, C., Kessler-Icekson, G., Feldberg, D., Nitke, S., and Ao, A. 2005. Mol. Hum. Reprod. 11: 229-236.

2. Andrews, M.C. 1951. Am. J. Obstet. Gynecol. 62: 28-37.

3. Angeletti, R.H. and Bradshaw, R.A. 1971. Proc. Natl. Acad. Sci. 68: 2417-2420.

4. Archibong, A.E., Petters, R.M., and Johnson, B.H. 1989. Biol. Reprod. 41: 1076-1083.

5. Dechant, G. and Barde, Y.A. 1997. Curr. Opin. Neurobiol. 7: 413-418.

6. Dissen, G.A., Hirshfield, A.N., Malamed, S., and Ojeda, S.R. 1995. Endocrinology 136: 4681-4692.

7. Dissen, G.A., Romero, C., Hirshfield, A.N., and Ojeda, S.R.
2001. Endocrinology 142: 2078-2086.

8. Flood, M.R., Gage, T.L., and Bunch, T.D. 1993. Theriogenology 39: 823-833.

9. Gabler, C., Killian, G.J., and Einspanier, R. 2001. Reproduction 122: 121-130.

10. Gandolfi, F., Modina, S., Brevini, T.A., Passoni, L., Artini, P., Petraglia, F., and Lauria, A. 1995. Mol. Reprod.Dev. 40: 286-291.

11. Jin, W., Arai, K.Y., Shimizu, K., Kojima, C., Itoh, M., Watanabe, G., and Taya, K. 2006. Endocrine 29: 155-160.

12. Lam, P.M., Briton-Jones, C., Cheung, C.K., Lok, I.H., Yuen, P.M., Cheung, L.P., and Haines, C. 2003. Biol. Reprod. 68: 1870-1876.

13. Leese, H.J. 1988. J. Reprod. Fertil. 82: 843-856.

14. Levi-Montalcini, R. 1987. Science 237: 1154-1162.

15. Li, C., Watanabe, G., Weng, Q., Jin, W., Furuta, C., Suzuki, A.K., Kawaguchi, M., and Taya, K. 2005. Zool. Sci. 22: 933-937.

16. Ojeda, S.R., Romero, C., Tapia, V., and Dissen, G.A. 2000. Mol. Cell. Endocrinol. 163: 67-71.

17. Papp, A.B., Somfai, T., Tartaglione, M., Varga, E., and Gardon, J.C. 2005. Acta. Vet. Hung. 53: 91-101.

18. Raffioni, S., Bradshaw, R.A., and Buxser, S.E. 1993. Аnnu. Rev. Biochem. 62: 823-850.

19. Sahlin, L., Meikle, A., Tasende, C., Lindberg, M., Masironi, B., and Eriksson, H. 2001. J. Steroid. Biochem. Mol. Biol. 77: 123-128.

20. Schell, D.L., Mavrogianis, P.A., Fazleabas, A.T., and Verhage, H.G. 1994. J. Soc. Gynecol. Investig. 1: 269276.

21. Shi, Z., Arai, K.Y., Jin, W., Weng, Q., Watanabe, G., Suzuki, A.K., and Taya, K. 2006. Biol. Reprod. 74: 850-856.

22. Shi, Z., Jin, W., Watanabe, G., Suzuki, A.K., Takahashi, S., and Taya, K. 2004. J. Reprod. Dev. 50: 605-611.

23. Snider, W.D. 1994. Cell 77: 627-638.

24. Sutter, A., Riopelle, R.J., Harris-Warrick, R.M., and Shooter, E.M. 1979. Prog. Clin. Biol. Res. 31: 659-667.

25. Verhage, H.G., Fazleabas, A.T., and Donnelly, K. 1988. Endocrinology 122: 1639-1645.

26. Weng, Q., Shi, Z., Kawaguchi, M., Watanabe, G., and Taya, K. 2008. J. Reprod. Dev. 54: 397-401.

27. White, K.L., Hehnke, K., Rickords, L.F., Southern, L.L., Thompson, D.L.Jr., and Wood, T.C. 1989. Biol.Reprod. 41: 425-430.

28. Willis, P., Sekhar, K.N., Brooks, P., and Fayrer-Hosken, R.A. 1994. J. Exp. Zool. 268: 477-485.

29. Wollenhaupt, K., Welter, H., Einspanier, R., Manabe, N., and Brüssow, K.P. 2004. J. Reprod. Dev. 50: 269-278. 